\begin{tabular}{|l|l|l|}
\hline \multicolumn{2}{|c|}{ PublisherInfo } \\
\hline \hline PublisherName & $:$ & BioMed Central \\
\hline \hline PublisherLocation & $:$ & London \\
\hline \hline PublisherImprintName & $:$ & BioMed Central \\
\hline \hline
\end{tabular}

\title{
Lymphocytes in lampreys?
}

\begin{tabular}{|l|l|l||}
\hline \multicolumn{2}{|c|}{ ArticleInfo } \\
\hline \hline ArticleID & $:$ & 3707 \\
\hline \hline ArticleDOI & $:$ & $10.1186 /$ gb-spotlight-20000622-02 \\
\hline \hline ArticleCitationID & $:$ & spotlight-20000622-02 \\
\hline \hline ArticleSequenceNumber & $:$ & 144 \\
\hline \hline ArticleCategory & $:$ & Research news \\
\hline \hline ArticleFirstPage & $:$ & 1 \\
\hline \hline ArticleLastPage & $:$ & 2 \\
\hline \hline & & RegistrationDate : 2000-06-22 \\
ArticleHistory & $:$ & OnlineDate $\quad$ 2000-06-22 \\
\hline \hline ArticleCopyright & $:$ & BioMed Central Ltd2000 \\
\hline \hline ArticleGrants & $:$ & \\
\hline \hline ArticleContext & $:$ & 130591111 \\
\hline \hline
\end{tabular}




\section{William Wells}

Email: wells@biotext.com

The adaptive immune system seems to have burst onto the evolutionary scene in a mere 50 million years, starting $\sim 500$ million years ago. Finding intermediate stages has proven difficult. In the June 20 Proceedings of the National Academy of Sciences Shintani et al. find that the lamprey, a jawless vertebrate reported to lack an adaptive immune system, expresses a member of the Spi family of lymphoid transcription factors (Proc. Natl. Acad. Sci. USA 2000, 97:7417-7422). Expression is limited to the ovary (inexplicably) and cells in the gut epithelium that morphologically resemble lymphocytes.

\section{References}

1. 'Big Bang' emergence of the combinatorial immune system.

2. Proceedings of the National Academy of Sciences, [http://www.pnas.org/] 